-Estudi-

\title{
THE EUROPEAN UNION'S EXTERNAL POLICY ON CLIMATE CHANGE ADAPTATION: FROM CONDITIONALITY-DRIVEN ACTION TO SUSTAINABLE DEVELOPMENT ${ }^{1}$
}

\author{
BEATRIZ PÉREZ DE LAS HERAS \\ Professor of European Union Law \\ University of Deusto (Bilbao) \\ beatriz.perez@deusto.es
}

Received: October 20th 2015 / Accepted: November 10th 2015

\begin{abstract}
The European Union (EU) has been promoting climate change adaptation measures in developing countries for the last 15 years. EU support is channeled through a number of external policies, but the development cooperation policy is particularly significant. Support has traditionally been conditional upon recipient countries' adopting a National Adaptation Plan (NAP). This conditionalitybased action has not only helped to promote NAPs in developing countries but also enabled these countries to participate in international climate governance. Yet this approach by itself, combined with certain inconsistencies, has failed to achieve sustainable development, one of the overarching goals of all EU policies. On the basis of this experience, the emphasis of the EU's external climate policy is currently shifting towards a broader approach that takes into account the three dimensions (economic, social and environmental) of sustainable development. This more comprehensive approach and corresponding tools are more in line with the EU's legal commitment to ensure Policy Coherence for Development.
\end{abstract}

RESUMEN: En los últimos 15 años, la Unión Europea (UE) ha venido impulsando la adopción de medidas de adaptación al cambio climático en países en vías de desarrollo.

\footnotetext{
${ }^{1}$ This articles draws on the paper submitted in the workshop on the "External Dimension of the European Union Environmental Policy" held in the Governance Innovation Week 1-5 June 2015 at the University of Pretoria (South Africa).
} 
El apoyo de la UE se canaliza a través de varias de sus políticas exteriores, siendo la de cooperación al desarrollo la más significativa a este respecto. Tradicionalmente, la ayuda europea ha estado condicionada a la adopción por los países receptores de un Plan Nacional de Adaptación (PNA). Esta iniciativa de la UE, basada en la condicionalidad, ha contribuido a la promoción de los PNAs en los países en desarrollo, al tiempo que les ha ayudado a implicarse en la gobernanza climática internacional. Con todo, este enfoque, por sí solo, junto con algunas incoherencias observadas, no ha conseguido propiciar un desarrollo sostenible, a pesar de constituir un objetivo trasversal de todas las políticas de la UE. Sobre la base de esta experiencia, la acción climática exterior de la UE transita en estos momentos hacia una visión más amplia que tiene en cuenta las tres dimensiones (económica, social y medioambiental) del desarrollo sostenible. Este enfoque más comprensivo, así como los correspondientes instrumentos empleados, parecen ir más en consonancia con la obligación jurídica de la UE de garantizar la coherencia de las políticas para el desarrollo.

RESUM: En els darrers quinze anys, la Unió Europea (UE) ha impulsat l'adopció de mesures d'adaptació al canvi climàtic a països en vies de desenvolupament. El suport de la UE es canalitza a través de diverses de les seves polítiques exteriors, essent la de cooperació al desenvolupament la més significativa al respecte. Tradicionalment, l'ajut europeu ha estat condicionat a l'adopció per part dels països receptors d'un Pla nacional d'adaptació (PNA). Aquesta iniciativa de la UE, basada en la condicionalitat, ha contribuït a la promoció dels PNAs en els països en desenvolupament, al mateix temps que els ha ajudat a implicar-se en la governança climàtica internacional. Amb tot, aquest enfoc, per si mateix, juntament amb algunes incoherències observades, no ha aconseguit propiciar un desenvolupament sostenible, malgrat constituir un objectiu transversal de totes les polítiques de la UE. Sobre la base d'aquesta experiència, l'acció climàtica exterior de la UE transita en aquests moments cap a una visió més àmplia, que té en compte les tres dimensions (econòmica, social i ambiental) del desenvolupament sostenible. Aquest enfoc més comprensiu, així com els instruments emprats, sembla que té més consonància amb l'obligació jurídica de la UE de garantir la coherència de les polítiques de desenvolupament. 
KEYWORDS: Conditionality — Climate Change Adaptation — Developing Countries — Sustainable Development — EU Development Policy.

PALABRAS CLAVE: Condicionalidad - Adaptación al cambio climático — Países en desarrollo — Desarrollo sostenible — Política de desarrollo de la UE.

PARAULES CLAU: Condicionalitat - Adaptació al canvi climàtic — Països en vies de desenvolupament — Desenvolupament sostenible — Política de desenvolupament de la UE.

SUMMARY: I. Introduction. II. Climate resilience in EU external action: conditionality as a catalyst of NAPs in developing countries. 1. Adaptation finance as a driving factor of the European development cooperation policy. 2. Inconsistencies and limits to sustainable development. III. Enhancing synergies between climate finance and development. 1. Climate compatible development as a new paradigm. 2. Towards a more integrated approach: promoting sustainable development in EU's external action. IV. Conclusion. V. Bibliography.

\section{INTRODUCTION}

It is widely recognized that climate change hits developing countries harder and will continue to do so, acting as an additional burden on the poorest and most vulnerable nations. Those most affected are the least developed countries (LDCs), which also have the lowest levels of greenhouse gas (GHG) emissions and have thus contributed least to climate change. ${ }^{2}$ The greatest need is, therefore, for funds for adaptation, ${ }^{3}$ which has traditionally been underfunded compared to mitigation ${ }^{4}$.

\footnotetext{
${ }^{2}$ As of 24 January 2014, the concept of LDC applies to 48 countries. List available at: $<$ http://unfccc.int/cooperation_and_support/ldc/items/3097.php>.

${ }^{3}$ In both human and natural systems, adaptation is defined as "a process of adjustment to actual or expected climate and its effects, in order to moderate harm or exploit beneficial opportunities." See INTERGOVERNMENTAL PANEL ON CLIMATE CHANGE (IPCC), Climate Change 2001: Impacts, Adaptation and Vulnerability. Third Assessment Report, Cambridge University Press, Cambridge, 2001, p.981.

${ }^{4}$ SCHALATEK, L. et al., "Climate Finance Thematic Briefing: Adaptation Finance", Climate Finance Fundamentals, 2012, p.1; NAKHOODA, S. et al., "Mobilising International Climate Finance: Lessons from the Fast-Start Finance Period”, World Resources Institute (WRI), 2013, pp. 4-5.
} 
Despite the economic recession still gripping the Eurozone, the EU and its Member States provide over $50 \%$ of global development aid..$^{5}$ A primary target of funding is climate-related action in poorer countries and most of the funding has traditionally gone on adaptation measures. To be eligible, the beneficiary countries must adopt national climate resilience strategies. This element of conditionality has acted as a catalyst for the promotion of National Adaptation Plans (NAPs) in developing countries. ${ }^{6}$

However, the EU's conditional support has not always been consistent with development aims in these countries. Some initiatives promoted by the EU have even had harmful effects for these economies, and been inconsistent with the targets of EU climate change policy.

Over the last three years, in line with the new post-2015 global agenda for sustainable development and with negotiations on a future post-Kyoto climate order, the EU seems to be setting up a more coherent approach to development aid and climate change by integrating the three dimensions of sustainable development (social, economic and environmental). Shifting its emphasis towards this approach, the EU and its Member States are currently striving to promote a more climate-compatible development policy. This approach goes beyond conditionality-based aid policy and supersedes the traditional separation between adaptation, mitigation and development strategies. It has also proved to be more in line with the wider and more universal approach of 'Policy Coherence for Development (PCD)' ${ }^{7}$

Against this background, this paper analyses and assesses the EU's external climate adaptation policy in its transition from conditionality-based support towards more integrated action focusing on sustainable development. It sets out to provide an overview of the EU's support to developing countries on climate change resilience in the framework of its development cooperation policy. The second part goes on to

\footnotetext{
${ }^{5}$ In 2014, EU collective aid increased to 58.2 billion euro, up 2.4 from 2013 . This represented $0.42 \%$ of the EU Gross National Income that year and was significantly higher than contributions from other donors. See "The EU remains the world's largest aid donor in 2014'. Consulted 5 October 2015, available at: <http://eu-un.europa.eu/articles/en/article_16293_en.htm>.

${ }^{6}$ The NAP is the instrument recommended by the United Nations Framework Convention on Climate Change (UNFCCC) to identify key adaptation needs for the country and to establish priority adaptation activities (Art.4, 1 e-f UNFCCC).

${ }^{7}$ The term originally emerged in the Organization for Economic Cooperation and Development (OECD) to emphasize the responsibility of developed countries to take into account the impact on developing countries when formulating domestic policies across different sectors (trade, finance, migration, etc.). OECD, "Policy Coherence for Development", Working Paper No.1, 2012. Consulted 5 October 2015, available at: <http://www.oecd.org/pcd/50461952.pdf $>$.
} 
explore the EU's new broader approach and tools for ensuring sustainable development in these countries, while assessing the consistency of this focus with the EU's commitment to PCD.

\section{CLIMATE RESILIENCE IN EU EXTERNAL ACTION: CONDITIONALITY AS A CATALYST OF NAPS IN DEVELOPING COUNTRIES}

Paralleling its actions in the internal area, the EU has rolled out a whole series of initiatives to help developing countries address the effects of global warming. Most efforts are focused on climate change adaptation projects. However, EU funding has not always proved to be the most effective way of addressing the needs of these vulnerable countries. Some inconsistencies and the lack of a comprehensive approach to climate change and development initiatives still prevent the objective of sustainable development from being achieved.

\section{Adaptation Finance as a Driving Factor of the European Development}

\section{Cooperation Policy}

One of the most important challenges faced by the EU and the international community at large is to identify how best to finance the costs of climate adaptation in developing countries. Recent estimates suggest that around 380 billion dollars are required per year to properly address adaptation shortfalls in Third World countries. ${ }^{8}$ The primary international sources of finance for adaptation projects in these countries are currently the UN and the EU. ${ }^{9}$ European aid is channeled through a number of external policies, including trade and neighborhood policies, but the development cooperation policy is particularly significant.

\footnotetext{
${ }^{8}$ MONTES, M., "Climate Change Financing Requirements of Developing Countries", Climate Policy Brief No. 1, 2013, p. 4; UN and Climate Change, "UNEP Report: Developing Countries' Adaptation Costs Likely To Far Surpass Previous Estimates", December 2014. Consulted 5 October 2015, available at: $<$ http://www.un.org/climatechange/blog/2014/12/unep-report-developing-countries-adaptation-costslikely-far-surpass-previous-estimates/>; KHARAS, H., PRIZON, A. and ROGERSON, A., Financing the Post-2015 Sustainable Development Goals. A Rough Roadmap, Overseas Development Institute (ODI), 2014, pp. 7-9, 12-16.

${ }^{9}$ CARAVANI, A., BARNARD, S., NAKHOODA, S. and SCHALATEK, L., "Climate Finance Thematic Briefing: Adaptation Finance", Climate Finance Fundamentals No. 3, 2014, p.1.
} 
Like the environment (including climate action), development cooperation is a policy of shared responsibility between the EU and its Member States, as provided for in Articles 4.4 and 208 of the Treaty on the Functioning of the European Union (TFEU). The ultimate aim is to promote sustainable economic growth in poorer countries, in consistence with Article 3.3 of the Treaty on European Union (TEU), which defines sustainable development as an overarching long-term goal of the EU. ${ }^{10}$ Specifically, Article 11 of the TFEU lays down the integration principle of environmental protection in all EU internal policies. It is also a policy goal of its external action, as provided by Article 21.2 (d) of the TEU. This objective is also in line with the multilateral legal framework currently provided by the UNFCCC and the future post-Kyoto climate order. $^{11}$

Eleven years ago, the strategic document used by the EU as the launch pad of its support for developing countries was the Climate Change Action Plan, in the context of Development Cooperation 2004-2008. ${ }^{12}$ The Action Plan was in consonance with the Millennium Development Goals and the results of the World Summit on Sustainable Development (Johannesburg 2002). ${ }^{13}$ Its strategic aims were to give greater political importance to climate change in development cooperation, to support adaptation and mitigation initiatives in poorer countries and to develop their capacities for climate resilience. Within this framework, the most important measure was undoubtedly the support provided to developing countries in identifying and assessing their vulnerability and in the consequent preparation of NAPs. In financial terms, the EU has contributed to preparing and implementing NAPs from its own funds and those provided by Member States.

As well as their own contributions, another outlet for adaptation financing by the EU and its Member States are the multilateral instruments specifically established for this

\footnotetext{
${ }^{10}$ The Sustainable Development Strategy (2001) provides the policy framework to address this legal commitment. After its review in 2009, it continues to be the long-term vision for EU policies until 2050. Consulted 5 October 2015, available at: $<$ http://europa.eu/legislation_summaries/environment/sustainable_development/128117_en.htm>.

${ }^{11}$ See EUROPEAN COMMISSION, "The Paris Protocol. A Blueprint for Tackling Global Climate Change Beyond 2020”, COM (2015) 81 final/2 of 4 March 2015, pp. 9-10

12 EUROPEAN COMMISSION, “Climate Change in the Context of Development Cooperation”, COM (2003) 85 final of 11 March 2003.

${ }^{13}$ UNITED NATIONS, "World Summit on Sustainable Development. Declaration on Sustainable Development", A/Conf. 199/20 (2002). Consulted 5 October 2015, available at: $<$ https://unfccc.int/files/cooperation_support/financial_mechanism/longterm_finance/application/pdf/montes_9_july_2012.pdf $>$.
} 
purpose. These include the Adaptation Fund, the Special Climate Change Fund and the Least Developed Fund. ${ }^{14}$ During COP-15 in Copenhagen, the EU and its Member States committed to contributing 7.2 billion euro of an estimated 20 billion provided for faststart financing in the period 2010-2012. They eventually exceeded that initial commitment, contributing a total of 7.34 billion euro, despite the serious economic recession faced by the Eurozone since 2010. They are currently preparing to meet the commitment assumed by developed countries to devote 100 billion dollars per year until 2020 to help underdeveloped countries identify vulnerabilities, priorities and strategies for action. ${ }^{15}$ At present, most of the bilateral and multilateral funds allocated prioritize adaptation measures, since mitigation is less relevant in poorer economies. ${ }^{16}$

Following the conclusion of the Action Plan in 2008, the principal instrument through which the EU and the Member States now channel their aid to developing countries is the Global Climate Change Alliance (GCCA). ${ }^{17}$ The GCCA is an EU initiative specifically designed to reinforce dialogue and cooperation with the countries that are most vulnerable to climate change, particularly least-developed countries and smallisland developing states (SIDS). It was initially set up with four countries in 2008; now, in 2015, 35 States and 8 regions and sub-regions are participating in this multilateral initiative, which is implementing over 45 national and regional programs, with a combined budget of close to 300 million euro. ${ }^{18}$

\footnotetext{
${ }^{14}$ These funds were created during the COP 7 in Marrakech (2001). Currently, there are more than 10 multilateral funds devoted to financing climate-related policies in developing countries. SVRAJE, D. and LISA, E., "The Marrakech Accords to the Kyoto Protocol: Analysis and Future Prospects", Global Environmental Change No. 26, 2007, pp. 149-153; Climate Funds Update, "The Funds", 2014. Consulted 5 October 2015, available at: $<$ http://www.climatefundsupdate.org/the-funds $>$.

${ }^{15}$ EUROPEAN COMMISSION, "European Union Climate Funding for Developing Countries in 2014", 2014, p. 3. Consulted 5 October 2015, available at: $<$ http://ec.europa.eu/clima/publications/docs/funding_developing_countries_2014_en.pdf $>$; WOLFF, G.B. and ZACHMANN, G., "European Climate Finance: Securing the Best Return", Bruegelpolicybrief No.3, 2015, pp.1-8.

${ }^{16}$ Confirming this trend, the multilateral funding for adaptation increased by $57 \%$ during the period 2013 2014. CARAVANI, "Climate finance...", cit., p.1. See also MORITA, K. and MATSUMOTO, K., "Financing Adaptation to Climate Change", in Handbook of Climate Change Adaptation, Springer Berlin Heidelberg, 2014, pp.1-19.

${ }^{17}$ Extensive information is available at: www.gcca.eu. As well as the GCCA, the European Investment Bank (EIB) - which is financed by EU Member States- is one of the international financial institutions that is providing most financing for climate actions, inside and outside Europe, especially in developing and emerging countries. In 2013, the EIB spent 19 billion euro on climate change projects worldwide. Of this amount 2.2 billion was invested in developing countries. COMMISSION, "European Union Climate Funding...”, cit., p.8.

${ }^{18}$ Ibid., p. 7.
} 
Through the GCCA, the EU and its Member States provide technical and financial support in five priority areas: mainstreaming climate change into poverty reduction and development efforts; adaptation; reduction of emissions from deforestation and forest degradation (REDD+); improvement in the clean development mechanism (CDM) and disaster risk reduction. In terms of the number of interventions, adaptation can perhaps be identified as the priority area at this time. ${ }^{19}$ Projects are being carried out in sectors that are especially vulnerable to the impact of climate change, such as agriculture and fishing, land management, water and waste, forests and natural resources. Most of the programs and projects are being implemented in countries in Africa, the Caribbean and the Pacific. ${ }^{20}$

To be eligible for European aid, the beneficiary countries must prepare and adopt a NAP. In this regard, it should be noted that a similar condition is currently imposed on Member States within the 2014-2020 Multiannual Financial Framework, which includes a share of climate-related expenditure of $20 \%$ of the EU budget. ${ }^{21}$ As indicated above, the NAP is the instrument recommended by the UNFCCC. It provides information on the country's general environmental and geographic setting, as well as on projected climate variability within the country and beyond. On the basis of this information, a NAP makes it possible to identify the country's key adaptation needs and establishes priority adaptation activities. ${ }^{22}$ Therefore, by encouraging developing countries to prepare NAPs, the EU can be said to be helping to bring these countries into the international climate governance regime.

\footnotetext{
${ }^{19}$ See information available at: $<$ http://www.climatefundsupdate.org/listing/global-climate-changeallianc\#TOC-Graphs-and-statistics>.

${ }^{20}$ Detailed information on projects, sectors and regions is available at: http://www.gcca.eu/technical-andfinancial-support.

${ }^{21}$ See EUROPEAN COMMISSION, Multiannual Financial Framework 2014-2020 and EU Budget 2014. The Figures, Publications Office of the European Union, 2013, pp. 7-13, 19. Consulted 5 October 2015, available at: <http://ec.europa.eu/budget/mff/index_en.cfm>. EU co-financing is conditional on the implementation of adaptation measures, which may become a useful tool for encouraging Member States that have not yet adopted a national adaptation strategy to do so. This condition is expressly set out in Article 8 of European Parliament and Council Regulation (EU) 1303/2013 of 17 December 2013, which establishes common provisions on the European Regional Development Fund, the European Social Fund, the Cohesion Fund, the European Agricultural Fund for Rural Development and the European Maritime and Fisheries Fund and general provisions on the European Regional Development Fund, the European Social Fund, the Cohesion Fund and the European Maritime and Fisheries Fund, and repeals Council Regulation (EC) 1083/2006 of 11 July 2006, OJ L347/320 of 20 December 2013. See EUROPEAN COMMISSION, Strategies and Instruments for Climate Proofing the EU Budget, 2011, pp. 67-69.

${ }^{22}$ See SABA, A. et al., "Climate Change Adaptation: Getting Ahead of the Curve", Carbon and Law Review No.1, 2013, pp. 13-14.
} 
At the same time, through this element of conditionality, the EU has been trying to generate sufficient capacity in these countries to enable them to receive aid in the long term and effectively manage funding to combat the effects of global warming. Likewise, this approach has served the EU itself as a catalyst for mainstreaming the climate factor in its development aid, thus having a multiplier effect. ${ }^{23}$

However, EU measures geared towards increasing climate resilience in developing countries are not always implemented in the best way nor are they the most suitable for addressing their needs. On the contrary, they can, paradoxically, become a barrier to the sustainable development of those countries.

\section{Inconsistencies in and Limits to Sustainable Development}

Indeed, although adaptation has the potential to reduce the negative impacts of climate change in developing countries, it can also exacerbate vulnerability, increase emissions and thereby undermine the social, economic and environmental objectives associated with sustainable development. These undesirable negative effects are observed when climate resilience action is mainstreamed into a traditional development paradigm, without establishing synergies between adaptation and sustainable development. The EU is no exception to this approach, traditionally followed by developed countries and donors. $^{24}$

One example of inconsistency between climate adaptation and development initiatives is the EU biofuels policy in developing countries. The Renewable Energy Directive mandates a use of $10 \%$ biofuels by transport in Member States by $2020 .{ }^{25}$ Subsidies from EU Member States promoting the use of biofuels in their domestic markets have encouraged a rapid increase in biofuel production in Africa, Asia and Latin America. European imports of biofuels from these regions have had negative consequences in

\footnotetext{
${ }^{23}$ See EUROPEAN COMMISSION, Paving the Way for Climate Compatible Development: Experiences from the Global Climate Change Alliance, 2012, pp 29-40.

${ }^{24}$ ERIKSEN, S. et al., "When not every response to climate change is a good one: identifying principles for sustainable adaptation", Climate and Development No.2, 2010, pp.1-14.

${ }^{25}$ Directive 2009/28/EC of the European Parliament and the Council on the promotion of the use of energy from renewable sources and amending and subsequently repealing Directives 2001/77/EC and 2003/30/EC of 23 April 2009, OJ L140 of 5 June 2009.
} 
some developing countries (for example, land grabbing, changes in land use and increased GHG emissions, higher food prices and insecurity). ${ }^{26}$

Evidence from case studies and feedback from experience also shows that adaptation and development fail to meet their objectives when initiatives do not integrate national and local contexts in planning and implementation. For example, the 2013 report on the GCCA identifies the absence of an overarching framework, overlapping institutional mandates and a lack of involvement by local communities as being some of the common limitations to effective implementation of adaptation projects in Gambia, Nepal and Cambodia, among others. ${ }^{27}$ The participation of civil society and local communities is regarded as being crucial if the social, economic and environmental elements required for sustainable development are to be consistently integrated. This process of consultation and negotiation with multiple groups requires time and resources, which are not always available, in part because of the urgency with which action is taken and sometimes because of difficulties deriving from the specific domestic context. As a result, adaptation and development initiatives may reflect only a narrow set of interests. ${ }^{28}$ For instance, evidence from the implementation of Mozambique's GCCA programme shows that powerful groups may be controlling who participates in the project selection process in order to favor their own interests. In this vein, the lack of political leverage of the Ministry for Coordination of Environmental Action over other ministries, combined with insufficient technical capacity and financial resources, is considered to be one of the most significant obstacles to the implementation of environmental sustainability in the country. This and other similar cases demonstrate that EU funding for adaptation strategies does not always take into account the establishment of cross-sectoral multi-stakeholder platforms at national and

\footnotetext{
${ }^{26}$ DIOP, D. et al., Assessing the impact of biofuels production on developing countries from the point of view of Policy Coherence for Development, Final Report, AETS Consortium, February 2013. Consulted 5 October 2015, available at: <http://ec.europa.eu/europeaid/sites/devco/files/study-impact-assesmentbiofuels-production-on-development-pcd-201302_en_2.pdf >; BOURGUIGNON, D., "EU Biofuels Policy. Dealing with Indirect Land Use Change", European Parliament Research Service, EPRS Briefing, February 2015.

${ }^{27}$ GCCA, From Integrated Climate Strategies to Climate Finance Effectiveness. Experiences from the Global Climate Change Alliance, 2013, pp. 34-48.

${ }^{28}$ TANNER, TH., "The Political Economy of Climate Change and Development”, IDS in Focus Policy Briefing, No.20, 2011, p.2. Consulted 5 October 2015, available at: <www.ids.ac.uk>.
} 
local levels, which would be necessary to channel their support in a more inclusive way. $^{29}$

Likewise, other inconsistencies between climate action and sustainable development goals arise because EU does not require companies in the extractive industry to sufficiently account for the environmental impact of their activities on local communities and ecosystems in developing countries. In 2013, the European Commission proposed that a 1978 Council Directive on this issue should be revised. However, the amended provisions are insufficient and poor, since they give companies excessive flexibility to choose which aspects to report on and which European or national framework to use. In the same sense, the absence of appropriate legislation on conflict minerals is also a source of inconsistency in EU policies. The European Parliament advocates such legislation in the form of an EU regulation that would require companies to explain the steps being taken to address risks in their supply chains from conflict minerals and ensure their purchases are legitimate. ${ }^{30}$

These inconsistencies and limitations highlight the lack of effective interaction between the EU's external adaptation policy and its development cooperation action. In addition, the EU development aid policy continues to be hindered by the fragmentation and duplication of Member States' aid policies. The absence of joint programming and aid coordination still brings an additional administrative burden and additional costs, ${ }^{31}$ undermining the effectiveness of European aid.

Therefore, development is not sustainable if it damages the environment and biodiversity, increases GHG emissions and vulnerability to natural disasters, and does not generate economic growth and social welfare. Climate mainstreaming and conditionality-based adaptation funding do not lead to sustainable development, but to

\footnotetext{
${ }^{29}$ Other shortcomings observed are insufficient information and data available to decision makers in developing countries, inadequate legal and regulatory frameworks, human and financial resource limitations in government services, the limited availability of specialized technical expertise and weaknesses in monitoring the performance of adaptation strategies. See GCCA, From Integrated Climate Strategies..., cit., pp.37-38.

${ }^{30}$ CONCORD, Spotlight on EU Policy Coherence for Development. The Real Life Impact of EU Policies on the Poor, Report 2013, 2014, pp.47-49; GRIEGER, G., "Minerals from Conflict Areas. Existing and New Responsible-Sourcing Initiatives", European Parliamentary Research Service, EPRS Briefing, 11 February 2014.

${ }^{31}$ Around $€ 800$ million per year. See EUROPEAN PARLIAMENT, "2013 Report of the EU on the Coherence of Development Policies”, A7-0161/2014, 6 March 2014, p.4.
} 
stronger aid dependency. Recognizing that this approach is in itself inefficient, ${ }^{32}$ the EU is currently focusing on integrating adaptation finance into sustainable development strategies.

\section{ENHANCING SYNERGIES BETWEEN CLIMATE FINANCE AND DEVELOPMENT}

As climate change issues are increasingly being integrated into broader development strategies, achieving synergies between climate finance and development is crucial. Promoting climate-compatible development is currently considered to be a good example of how to address this target. The ultimate aim is to promote sustainable development by integrating comprehensive climate change responses into national development strategies. The EU and its Member States are committed to achieving this goal.

\section{Climate Compatible Development as a New Paradigm}

Climate compatible development (CCD) is a new approach that seeks to interlink climate strategies and development goals consistently. More specifically, CCD strives to minimize the harm caused by climate change and maximize the economic growth and social development opportunities presented by a more resilient, low-emission, future. In practice, this means creating synergies between policies which to date have tended to function separately, such as adaptation, mitigation and development. ${ }^{33}$

In particular, adaptation is one aspect of climate policy which naturally overlaps with development, given that climate-vulnerability and poverty reduction are key factors for adaptation. This overlap is known as 'climate resilient development', an economic growth model that provides the capacity to absorb and quickly bounce back from climate stresses. The concept clearly goes further than traditional development, since it chiefly identifies ways in which society can learn to generate its own sustainable transformations. ${ }^{34}$

\footnotetext{
${ }^{32}$ EUROPEAN COMMISSION, "European Union Climate Funding for Developing Countries in 2013", 2013, pp.6-7. Consulted 5 October 2015, available at:

$<$ http://ec.europa.eu/clima/events/docs/0086/funding_en.pdf $>$.

${ }^{33}$ MITCHELL, T. and MAXWELL, S., "Defining Climate Compatible Development", Climate Development Knowledge Network CDK Police Brief, November 2010, p.1.

${ }^{34}$ Ibid., p. 4.
} 
The effective implementation of CCD strategies requires strong coordination among individuals, civil society groups, institutions and national governments. However, the subnational level is considered to be more appropriate for this task, given that climate policies always need to be implemented at this scale. In addition, local institutions face more intensive pressure to act on the negative impacts of climate extremes and disasters. ${ }^{35}$ One example of an effective strategy for subnational CCD is 'communitybased adaptation' (CBA), an emerging climate and development approach that aims to build the resilience of vulnerable individuals and communities from the bottom up. ${ }^{36}$ In this context, communities themselves identify their adaptation needs and priorities and take action. It is therefore a community-driven approach to adaptation that complements top-down programs. ${ }^{37}$ At present, hundreds of CBA initiatives are being implemented in Asia, Africa and Latin America. For instance, Bangladesh has been a pioneer in CBA and now has a growing Non-Governmental Organizations (NGOs) sector which is supporting initiatives throughout the country. Indeed, Bangladesh has been dubbed the 'adaptation capital of the world'. ${ }^{38}$ Another example is 'farmer-managed natural regeneration' in Niger, a project that aims to reduce erosion and provides a continuous harvest of fuel, building materials, food and fodder without the need for replanting. Around 4.5 million people benefit and local communities are increasing their resilience. ${ }^{39}$ Zambia has also pioneered community-based agroforestry and conservation farming programs as a way of achieving long-term soil fertility and high agricultural yields. $^{40}$

\footnotetext{
${ }^{35}$ ANTON, B. et al., "Close to Home: Subnational Strategies for Climate Compatible Development", CDKN Working Paper, April 2014, pp. 3-5.

${ }^{36}$ GOGOI, E. et al., "How to Scale out Community-Based Adaptation to Climate Change", $C D K N$ Working Paper, April 2014, pp. 1-2.

${ }^{37}$ INTERNATIONAL INSTITUTE FOR ENVIRONMENT AND DEVELOPMENT (IIED), “Assessing the CBA Community of Practice?", IIED briefing, April 2013. Consulted 5 October 2015, available at: http://pubs.iied.org/17152IIED.
}

${ }^{38}$ HUQ, S., "Climate Change experts head to adaptation capital of the world", IIED Press Release. Consulted 5 October 2015, available at: $<$ www.iied.org/climate-change-experts-head-adaptation-capitalworld $>$.

${ }^{39}$ RINAUDO, T., About Farmer Managed Natural Regeneration, World Vison Australia, pp.2-3. Consulted 5 October 2015, available at: <http://www.worldvision.org/resources.nsf/main/pressresources/\$file/farmer-managed-natural-regeneration.pdf $>$.

${ }^{40}$ GOGOI, "How to scale...", cit., pp 2 and 6; WARD, M., "An Integrated System of Agro-Forestry in Zambia", CDKN Inside Stories, December 2011. Consulted 5 October 2015, available at: $<$ http://pdf.wri.org/inside_stories_zambia.pdf $>$. 
Though promising in terms of sustainable development, CBA has accumulated little experience and has largely focused on adaptation initiatives. However, a growing body of evidence shows that donor funds are increasingly being channeled into CCD initiatives. ${ }^{41}$ Substantial funds are now being promised and directed to climate-resilient and low-emission paths with the aim of reducing both climate vulnerability and poverty. ${ }^{42}$ This aspect became central to the discussions on a new post-2015 sustainable development framework and a post-2020 world climate order. ${ }^{43}$ Indeed, supporting CCD initiatives is a key objective of the process of ensuring PCD. In the context of the discussions on a post-2015 sustainable development framework, PCD was reconceptualized by the OECD and is now described as a process that integrates multiple development aspects at all stages of policy-making with three main objectives: ${ }^{44}$

\section{Policy Coherence for Development}

\footnotetext{
${ }^{41}$ Many OECD countries have insistently expressed the view that climate financing and development financing are closely linked at the project level and impossible to separate (OECD, A Post-2015 Information System for International Development and Climate Finance. Submitted to the High Level Panel on the Post-2015 Development Agenda, 2013). Consulted 5 October 2015, available at: http://www.oecd.org/dac/stats/climate-change.htm. In this same line, paragraph 34 of the 2011 Busan Partnership for Effective Development Cooperation specifically refers to the need to promote enhanced coherence, transparency and predictability across approaches for effective climate change finance and broader development cooperation. Text available at: http://www.oecd.org/dac/effectiveness/49650173.pdf

${ }^{42}$ KLINSKY, S. et al., Building Climate Equity. Creating a New Approach from the Ground Up, World Resource Institute (WRI), Summary Report, 2014, especially pp.5-10.

${ }^{43}$ See SUSTAINABLE DEVELOPMENT KNOWLEDGE PLATFORM, "Targets in the proposed SDGs Framework". Consulted 5 October 2015, available at: $<$ https://sustainabledevelopment.un.org/post2015/sdgsandtargets $>$.

${ }^{44}$ KNOLL, A., "Bringing Policy Coherence for Development into the Post-2015 Agenda-Challenges and Prospects", European Centre for Development Policy Management (ECDPM) Discussion Paper No.163, 2014, p.3.
} 
Address the negative

spillovers of domestic

policies on long-term

development prospects
Increase governments' capacities to

identify trade-offs and reconcile

domestic policy objectives with

internationally agreed objectives

Foster synergies across economic,

social and environmental policy

areas to support sustainable

development

Source: OECD, Better Policies for Development: Policy Coherence and Illicit Financial Flows (2014,

p. 16)

The EU incorporated PCD as a legal commitment through the Lisbon Treaty (2009). In this vein, Article 208 of the TFEU states that 'The Union shall take account of the objectives of development cooperation in the policies that it implements which are likely to affect developing countries' ${ }^{45}$ At the same time, as indicated above, sustainable development is an overarching and long-term goal of all policies of the EU, including its external action, as provided by Article 21.2 (d) of the TEU. In its Communication "A Decent Life for All. From Vision to Collective Action", the European Commission committed itself to promoting PCD, whilst encouraging both developed and developing countries to promote policy coherence and contribute to the implementation of the post-2015 framework. ${ }^{46}$ As a broader aim, the European Commission and some Member States, such as the Netherlands and the UK, pushed for "policy coherence for sustainable development", in their statements within the United Nations Open Working Group (OWG) on Sustainable Development Goals. ${ }^{47}$ This concept shifts emphasis towards a more coherent approach that integrates and balances the three dimensions of sustainable development. The term also appears in the Council

\footnotetext{
${ }^{45}$ PCD became a political commitment for the EU through the European Consensus on Development (2005). At that time, it aimed at enhancing the compatibility of EU policies with the Millennium Development Goals. The European Commission initially identified 12 priority areas in which synergies with development policy objectives were important. In 2009, these areas were clustered into five main PCD challenges: trade and finance, climate change, food security, migration and security. Since 2005, the European Commission issues a biennial report on PCD progress across different policy areas. See EUROPEAN COMMISSION, "Policy Coherence for Development. 2015 EU Report", Staff Working Document, SWD (2015) 159 final of 3 August 2015, pp. 11-12.

${ }^{46}$ EUROPEAN COMMISSION, “A Decent Life for All: from Vision to Collective Action”, COM (2014) 335 final of 2 February 2014. In particular, see point 5 "A new Global Partnership".

${ }^{47}$ KNOLL, "Bringing Policy Coherence...", cit, p.5.
} 
Conclusions on a Transformative Post-2015 Agenda as a strategy conducive to the success of the new framework. ${ }^{48}$ However, "policy coherence for sustainable development" has not as yet been taken as an overarching concept at global level, but the EU has already mainstreamed this approach and shows a willingness to implement it.

\section{Towards a more Integrated Approach: Promoting Sustainable Development in}

\section{EU's External Action}

Eradicating poverty and achieving sustainable development are critical challenges the international community will have to address in the process of implementing the post2015 agenda, adopted at the UN Summit of September $2015 .{ }^{49}$ Commitments on these issues will also have important implications for the new post-Kyoto climate order. Together with its Member States, the EU, has committed itself to both processes, trying to provide key inputs and make constructive proposals. ${ }^{50}$ Drawing on the Council Conclusions on a transformative post-2015 agenda, in February 2015 the European Commission proposed a global partnership as a key instrument for implementing the post-2015 sustainable development framework. According to the Commission, the global partnership should be based on the principles of shared responsibility, mutual accountability and respective capacity and all countries should participate in its implementation. It would promote the integration of the three dimensions of sustainable development and require policy coherence at all levels to reduce poverty and achieve sustainable development. ${ }^{51}$

\footnotetext{
${ }^{48}$ COUNCIL OF THE EUROPEAN UNION, "Council Conclusions on a Transformative post-2015 Agenda", Brussels, 16 December 2014, p.5.

${ }^{49}$ See "UN Adopts New Global Goals, Charting Sustainable Development for People and Planet by 2030". Consulted 5 October 2015, available at: $<$ https://sustainabledevelopment.un.org/?page=view\&nr=971\&type=230\&menu=2059>.

${ }^{50}$ Numerous documents delivered by both the European Commission and the Council over recent years articulate the EU's contribution to the post-2015 framework. In addition to those cited above, see Commission Communications on "A Decent Life for all: Ending Poverty and Giving the World a Sustainable Future", COM(2013) 92 of 27 February 2013, and "Beyond 2015: Towards a Comprehensive and Integrated Approach to Financing Poverty Eradication and Sustainable Development', COM(2013) 531 of 16 July 2013, and Council Conclusions on "The Overarching Post-2015 Agenda" of 25 June 2013 (doc. 11559/13) and "Financing Poverty Eradication and Sustainable Development beyond 2015" of 12 December 2013 (doc.16827/14).

${ }^{51}$ EUROPEAN COMMISSION, “A Global Partnership for Poverty Eradication and Sustainable Development after 2015”, COM (2015) 44 final of 5 February 2015, pp-2-3.
} 
In line with these proposals and with the specific goal of ensuring sustainable development, the EU is now trying to promote comprehensive climate strategies that combine measures for climate resilience and low emission as an essential part of national development frameworks. In this line, developing countries are being encouraged to prepare more comprehensive adaptation strategies, either through NAPs or JNAPs (Joint National Action Plans), as more strategic and integrated tools that address disaster risk reduction and climate change adaptation. ${ }^{52}$ This approach is in line with the aim of integrating disaster risk management and climate resilience in the post2015 development framework addressing poverty eradication and sustainable development. ${ }^{53}$ As regards mitigation, the EU is supporting National Appropriate Mitigation Actions (NAMAs) as flagship policies that combine national adaptation plans with low emission strategies, linking the benefits with development strategies. Likewise, such Member States as Germany and the UK are promoting the NAMA Facility, an initiative launched by the two governments in 2012 as a result of the COP18 in Doha. They jointly contribute an initial $€ 70$ million of funding to encourage developing countries to advance innovative and transformative NAMAs geared towards sustainable low-carbon development paths in the coming years. In early 2015, Denmark and the European Commission joined the Facility as additional donors. ${ }^{54}$

Support for NAMAs in achieving transformational change towards sustainable development is also part of the global initiative known as the 'Low Emission Capacity Building Program' (LECBP), launched in January 2011 as part of a joint collaboration between the EU (European Commission and Member States) and the UN Development Program. It currently has 25 participating countries which receive technical support through contributions from the EU, Germany and Australia. ${ }^{55}$ It may be concluded,

\footnotetext{
${ }^{52}$ See, for example, some case studies in the Pacific region in UNITED NATIONS OFFICE FOR DISASTER RISK REDUCTION (UNISDR), The Pacific Experience in Developing Policy and Legislation on Disaster Risk Reduction and Climate Change Adaptation, UNISDR, 2013, pp.4-28.

${ }^{53}$ See "Sendai Framework for Disaster Risk Reduction 2015-2030", adopted by the Third World Conference on Disaster Risk Reduction, held from 14 to 18 March 2015 in Sendai (Japan), A/CONF.224/CRP.1 This initiative completes and reinforces the "Hyogo Framework for Action 20052015: Building Resilience of Nations and Communities to Disasters", A/CONF.206/6.

${ }^{54}$ The NAMA Facility is currently supporting projects in Burkina Faso, Chile, Indonesia, Thailand, Tajikistan, Mexico, Costa Rica, Colombia and Peru. More information available at: $<$ http://www.namafacility.org/start.html>.

${ }^{55}$ Apart from NAMAs, the LECBP includes Low Emission Development Strategies (LEDS), a more coherent approach to low-emission development, which combines low-carbon development strategies and climate-compatible development plans. It also supports Measuring, Reporting and Verification (MRV) as part of the UN Development Programme's Larger Green, Low-Emission and Climate-Resilient
} 
therefore, that the EU policy is more in line with current global initiatives geared towards supporting developing countries' efforts to address climate vulnerability in alignment with national development priorities.

In this integrated approach, a growing number of projects supported by both the EU and Member States also link economic development and poverty reduction with mitigation and adaptation strategies. Thus, the EU, through the GCCA, is currently supporting country-led initiatives to develop integrated climate change strategies that address both adaptation and mitigation needs in such countries as Gambia, Lesotho, Mali, Myanmar, Bangladesh and the Comoros. ${ }^{56}$ Other recent initiatives aimed at building resilience and promoting the development of the most vulnerable are "Supporting the Horn of Africa's Resilience" (SHARE), born out of the 2011 Horn of Africa food crisis, ${ }^{57}$ and "Alliance Globale pour l'Initiative Resilience Sahel" (AGIR), launched in 2012 for the West Africa region. ${ }^{58}$

Likewise, most Member States are currently trying to contribute to the promotion of this integrated approach to climate and development. For instance, Sweden is currently supporting two innovative initiatives in Cambodia - the Cambodia Climate Change Alliance (CCCA) and Local Climate Adaptive Living Facility (LoCAL) - which promote climate resilience activities aligned with national development priorities. ${ }^{59}$ Ireland contributes $€ 2.5$ million to a 5 -year project on disaster risk reduction, energy availability, health, agriculture, water and sanitation infrastructure in Zambia. This project is framed within Zambia's Sixth National Development Plan (2013-2016), and focuses especially on rural development. ${ }^{60}$ In the same vein, the Netherlands is funding the Sustainable Agriculture, Food Security and Market Linkages (SaFal) project in

Development Strategies. See COLON, CR., UNDP Low Emission Capacity Building (LECB)

Programme: A Global Initiative to Support Mitigation Action-LEDS, NAMAs \& MRV, UNDP, 2013.

Consulted 5 October 2015, available at:

$<\mathrm{https}$ ://unfccc.int/files/cooperation_and_support/capacity_building/application/pdf/df2cbm02.pdf $>$.

${ }^{56}$ GCCA, From Integrated Climate Strategies...., cit., pp. 10-24.

${ }^{57}$ Consulted 5 October 2015, information available at:

$<$ http://ec.europa.eu/echo/files/aid/countries/factsheets/hoa_en.pdf $>$.

${ }^{58}$ Consulted 5 October 2015, information available at:

$<$ http://ec.europa.eu/echo/files/aid/countries/factsheets/sahel_agir_fr.pdf)>.

${ }^{59}$ Specifically, CCCA supports the development of the first Cambodia Climate Change Strategic Plan (2014-2023), whereas LoCAL focuses on integrating adaptation into local government's planning and budgets. See COMMISSION, "European Union Climate...", cit., p.14.

${ }^{60}$ Ibid., p. 16. 
Bangladesh. Implementation of this initiative began on 1 November 2012 and it will conclude on 31 October 2016. SaFal provides a clear example of integrating climate change adaptation into the development program of this country. Its major goal is to improve food security by developing sustainable agricultural practices and market chains in horticulture and animal husbandry. ${ }^{61}$

Combining economic growth and environmental sustainability is, therefore, gradually becoming a key policy of both the EU and its Member States. The EU's current multiannual financial framework 2014-2020 sets the goal of assigning 20\% of the EU's annual budget to climate-related projects (representing a total of $€ 190$ billion). This ambitious financing target includes development cooperation policies, with 1.7 billion euro allocated to climate measures in this area in the period 2014-2015. ${ }^{62}$ Specifically, climate-relevant activities in developing countries and economies in transition are being funded through such instruments as the Development Cooperation Instrument, which supports environmental sustainability and climate change-related projects within the thematic program "Global Public Goods and Challenges". Countries on the OECD Development Assistance Committee (DAC) list of Official Development Assistance (ODA) may be recipients of this funding. ${ }^{63}$

Consequently, in keeping with this new approach, development and climate finance now appear to be more intrinsically linked in the EU's external action. The challenge now is to ensure consistent articulation between the two and avoid overlapping initiatives and formalities between the EU, its Member States and other donors. Likewise, despite a reiterated political commitment and development-friendly rhetoric, achieving actual PCD is still a challenge, given that some ambiguities and shortcomings remain in EU policies. Among others, these include a lack of appropriate systems for gathering data about the impact of EU policies on the livelihoods of local communities

\footnotetext{
${ }^{61}$ See JAGORANI CHAKRA FOUNDATION, Sustainable Agriculture, Food Security and Linkages. Consulted 5 October 2015, available at: $<$ http://www.jcfbd.org/index.php/programmesd/sustainablelivehood/sustainable-agriculture-food-security-linkagessafal.html>.

${ }^{62}$ Within the current multiannual framework, development cooperation is part of Heading 4. Global Europe. This EU policy has a budget of 66.2 billion euro, representing $6.12 \%$ of the overall budget for 2014-2020. See COMMISSION, Multiannual Financial Framework..., cit., pp.21-22.

${ }^{63}$ The current DAC list is available at: $<$ http://www.oecd.org/dac/stats/documentupload/DAC\%20List\%20of\%20ODA\%20Recipients\%202014 $\% 20$ final.pdf $>$.
} 
in developing countries. ${ }^{64}$ Efficient integration of climate change responses in relevant development planning processes will therefore continue to be essential for achieving a transformative transition to a low-carbon, climate-resilient, developing and developed world.

\section{CONCLUSION}

Since the 2000s, the EU has been playing an active role in promoting climate change adaptation in developing countries, particularly within the framework of its development cooperation policy. The EU's financial support has been conditional upon the recipient countries' adopting NAPs. The EU has contributed to the preparation and implementation of NAPs, from its own funds and those of its Member States. The ultimate aim is to promote sustainable economic growth in poorer countries and at the same time to bring them into the international climate governance regime. However, mere climate mainstreaming into development cooperation policy and conditionalitybased adaptation funding has not led to sustainable development. Instead, the lack of an integrated approach, together with other inconsistencies, has increased climate vulnerability and aid dependency in target countries.

Over the last three years the EU and its Member States have been actively involved in international negotiations leading to a post-2015 sustainable development agenda and a post-2020 climate order. In the framework of these processes, the EU's climate resilience approach towards developing countries has become gradually broader and more consistently integrated into national development policies. Likewise, strong involvement of civil society and multi-level approaches (local, national, regional, global) are now being promoted to reduce vulnerability and build resilience as conditions for poverty reduction and sustainable development. In keeping with this drive, the EU is currently promoting comprehensive climate policies that may prove to be more compatible with development. Along these lines, as a legal commitment for the EU, boosting PCD has a key contribution to make in establishing this policy as the universal standard to encourage the convergence of all countries' policies towards

\footnotetext{
${ }^{64}$ Increasingly involved in the promotion of PCD, the European Parliament has proposed concrete measures to improve the PCD institutional framework and implementation tools. Its key proposals include an EU arbitration mechanism and an independent complaint system open to people from developing countries. See LATEK, M., "Policy Coherence for Development: Still Some Way to Go", European Parliamentary Research Service, EPRS Briefing, May 2015, p.4.
} 
poverty eradication and sustainable development. In practice, however, the EU's institutional mechanisms and tools for correcting incoherent policies will still need to be improved if PCD is actually to be delivered.

The post-2015 sustainable development agenda makes PCD even more crucial. The EU has the opportunity to lead the process by building synergies between its policies that benefit developing countries and, consequently, demonstrating that it is taking its PCD obligations seriously.

\section{REFERENCES}

ANTON, B. et al., "Close to Home: Subnational Strategies for Climate Compatible Development", CDKN Working Paper, April 2014.

SJAFJELL, B. and WIESBROCK, A., The Greening of European Business under EU Law. Taking article 11 TFEU Seriously, Routledge, 2015.

BOURGUIGNON, D., "EU Biofuels Policy. Dealing with Indirect Land Use Change”, European Parliament Research Service, EPRS Briefing, February 2015.

CARAVANI, A., BARNARD, S., NAKHOODA, S. and SCHALATEK, L., "Climate Finance Thematic Briefing: Adaptation Finance", Climate Finance Fundamentals No.3, 2014.

COLON, CR., UNDP Low Emission Capacity Building (LECB) Programme: A Global Initiative to Support Mitigation Action-LEDS, NAMAs \& MRV, UNDP, 2013. Consulted 5 October 2015, available at: $<$ https://unfccc.int/files/cooperation_and_support/capacity_building/application/pdf/df2 cbm02.pdf $>$.

CONCORD, Spotlight on EU Policy Coherence for Development. The Real Life Impact of EU Policies on the poor, Report 2013, 2014.

DIOP, D. et al., Assessing the impact of biofuels production on developing countries from the point of view of Policy Coherence for Development, Final Report, AETS Consortium, February 2013. Consulted 5 October 2015, available at: $<$ http://ec.europa.eu/europeaid/sites/devco/files/study-impact-assesment-biofuelsproduction-on-development-pcd-201302_en_2.pdf $>$. 
ERIKSEN, S. et al., "When not every response to climate change is a good one: identifying principles for sustainable adaptation", Climate and Development No.2, 2010.

GLOBAL CLIMATE CHANGE ALLIANCE (GCCA), From Integrated Climate Strategies to Climate Finance Effectiveness. Experiences from the Global Climate Change Alliance, 2013.

GOGOI, E. et al., "How to Scale out Community-Based Adaptation to Climate Change", CDKN Working Paper, April 2014.

HUQ, S., "Climate Change experts head to adaptation capital of the world", IIED Press Release. Consulted 5 October 2015, available at: <www.iied.org/climate-changeexperts-head-adaptation-capital-world $>$.

INTERGOVERMENTAL PANEL ON CLIMATE CHANGE (IPCC), Climate Change 2001: Impacts, Adaptation and Vulnerability. Third Assessment Report, Cambridge University Press, Cambridge, 2001.

INTERNATIONAL INSTITUTE FOR ENVIRONMENT AND DEVELOPMENT (IIED), "Assessing the CBA Community of Practice?", IIED briefing, April 2013. Consulted 5 October 2015, available at: <http://pubs.iied.org/17152IIED>.

JAGORANI CHAKRA FOUNDATION, Sustainable Agriculture, Food Security and Linkages. Consulted 5 October 2015, available at: <http://www.jcfbd.org/index.php/programmesd/sustainablelivehood/sustainable-agriculture-foodsecurity-linkages-safal.html>.

KHARAS, H., PRIZON, A. and ROGERSON, A., Financing the Post-2015 Sustainable Development Goals. A Rough Roadmap, Overseas Development Institute (ODI), 2014.

KLINSKY, S. et al., Building Climate Equity. Creating a New Approach from the Ground Up, World Resource Institute (WRI), Summary Report, 2014.

KNOLL, A., "Bringing Policy Coherence for Development into the Post-2015 AgendaChallenges and Prospects", European Centre for Development Policy Management (ECDPM) Discussion Paper No.163, 2014.

JORDAN, A. and LENSCHOW, A., "Environmental Policy Integration: a State of the Art Review”, Environmental Policy and Governance No.20, 2010. 
LATEK, M., "Policy Coherence for Development: Still Some Way to Go", European Parliamentary Research Service, EPRS Briefing, May 2015.

LENSCHOW, A., Environmental Policy Integration: Greening Sectoral Policies in Europe, Earthscan, 2002.

MARÍN DURÁN, G. and MORGERA, E., Environmental Integration in the EU's External Relations: Beyond Multilateral Dimensions, Hart, 2012.

MITCHELL, T. and MAXWELL, S., "Defining Climate Compatible Development", Climate Development Knowledge Network CDK Police Brief, November 2010.

MONTES, M., "Climate Change Financing Requirements of Developing Countries", Climate Policy Brief No.1, 2013.

MORITA, K. and MATSUMOTO, K., "Financing Adaptation to Climate Change", in Handbook of Climate Change Adaptation, Springer Berlin Heidelberg, 2014, pp.1-19.

NAKHOODA, S. et al.,"Mobilising International Climate Finance: Lessons from the Fast-Start Finance Period”, World Resources Institute (WRI), 2013.

NILSSON, M. and PERSSON, A., "Framework for Analyzing Environmental Policy Integration”, Journal of Environmental Policy \& Planning No. 4, 2003.

OECD, "Policy Coherence for Development", Working Paper No.1, 2012.

- A Post-2015 Information System for International Development and Climate Finance. Submitted to the High Level Panel on the Post-2015 Development Agenda, 2013. Consulted 5 October 2015, available at: http://www.oecd.org/dac/stats/climatechange.htm.

RINAUDO, T., About Farmer Managed Natural Regeneration, World Vison Australia, pp.2-3. Consulted 5 October 2015, available at: $<$ http://www.worldvision.org/resources.nsf/main/press-resources/\$file/farmer-managednatural-regeneration.pdf $>$.

SABA, A. et al., "Climate Change Adaptation: Getting Ahead of the Curve", Carbon and Law Review No.1, 2013.

SCHALATEK, L. et al., "Climate Finance Thematic Briefing: Adaptation Finance", Climate Finance Fundamentals, 2012. 
SUSTAINABLE DEVELOPMENT KNOWLEDGE PALTFORM, "Targets in the proposed SDGs Framework". Consulted 5 October 2015, available at: $<$ https://sustainabledevelopment.un.org/post2015/sdgsandtargets $>$.

SVRAJE, D., LISA, E., "The Marrakech Accords to the Kyoto Protocol: Analysis and Future Prospects", Global Environmental Change No.26, 2007.

TANNER, TH., "The Political Economy of Climate Change and Development", IDS in Focus Policy Briefing, No.20, 2011.

UNITED NATIONS OFFICE FOR DISASTER RISK REDUCTION (UNISDR), The Pacific Experience in Developing Policy and Legislation on Disaster Risk Reduction and Climate Change Adaptation, UNISDR, 2013.

WARD, M., "An Integrated System of Agro-Forestry in Zambia”, CDKN Inside Stories, December 2011. Consulted 5 October 2015, available at: $<$ http://pdf.wri.org/inside_stories_zambia.pdf $>$.

WOLFF, G.B. and ZACHMANN, G., "European Climate Finance: Securing the Best Return”, Bruegelpolicybrief No.3, 2015. 